\title{
The Role of Good Governance in the Performance of a Public Entity (The Case of ARDA)
}

\author{
BLERINA BANUSHI ${ }^{1}$, VALBONA CINAJ ${ }^{2}$, ARTUR RIBAJ $^{3}$, \\ ${ }^{1}$ Department of Finance and Accounting, Faculty of Economics, LOGOS, ALBANIA \\ ${ }^{2}$ Department of Statistics, Informatics, and Applied Math., University of Tirana, ALBANIA \\ ${ }^{3}$ Faculty of Economics, Tirana University, ALBANIA
}

Abstract: - This study aims to provide an overview of central governance in Albania, focusing on farmers' opinion and satisfaction with activity of Agriculture Rural Development Agency (ARDA) in Albania, which is financed by public and EU funds either for financing or credit guarantying the Albanian Farmers.

Thus, what is the farmers' perception for ARDA activity and what would the subsidized farmers like to change or improve on governmental agency service delivery? This is followed by the well-known assumption that citizens rely on personal experiences when they create their own views, which are closely related to their knowledge and understanding of central government performance as a starting point for good governance, and in some cases, they can make central authorities liable for issues that are not under their direct control.

For this reason, the main purpose of this research is to evaluate main stakeholders' perception such as: the employees and high-level officials of ARDA, as service providers, and farmers or entrepreneurs in five districts of Albania as: Tirana, Berat, Fier, Elbasan and Durrës (randomly selected), as beneficiaries of these services. In this context, it is also interesting to find a correlation between their perceptions on performance of public services delivered, in order to increase performance and real welfare.

The measurement of the perception of satisfaction was finalized by combining quantitative and qualitative research techniques. The combination of these methods has been used to derive the necessary results and to understand the essential role of good governance in the performance of the public entities in Albania.

The results of this study highlight the most prominent problems of ARDA as well as the perception that subsidized farmers, in the above-mentioned districts, have for their opportunities, role and influence on important issues such as transparency, accountability, rule of law and citizen participation. According to the farmers' perception, all the performance indicators of ARDA that have been analyzed in this study are not at the expected level. Therefore, it is concluded that ARDA needs further performance improvement, in order to provide a quality service. Consequently, the understanding of farmers' perception on central governance, whether true or perceived, is an important part of improving effectiveness and efficiency, providing services and improving accountability of central administration.

Keywords: -Performance, governance, financing, audit, public entity, farmer.

Received: January 25, 2021. Revised: June 17, 2021. Accepted: June 25, 2021. Published: July 2, 2021. 


\section{Introduction}

Good governance is the backbone of democracy, as it affects the everyday life of citizens through the way it interacts with them and serves them. From this point of view, an effective governance requires a mutual communication with the citizens. The governance performance and the way it interacts with citizens influence the behavior of the latter, as well as the intercommunity relations, cohesion, and trust within and between communities; this legitimizes government efforts and promotes sustainable development. Institutional performance in public sector, also called governmental performance, is often measured by indicators (IPI) related to resources and outcomes, but there is an increasing consensus of the fact that monetary resources are not enough. Obviously, the results of governance are difficult to measure objectively.

Good governance is a relatively new concept, originally undertaken in the fight against corruption and anti-informality, at the beginning of this millennium. It has expanded by attempting to connect on its conceptual basis with the new notion of development and become part of it. Today it represents a global phenomenon called "New Public Management", which was first coined since 1991 [1]. For this study we searched on previous articles from various authors, $[2 ; 3$; $4 ; 5 ; 6 ; 7]$ on the field of CG and its role in the performance of public entities. "New Public Management" was described as a "Marriage of opposites', one of which is the new institutional economics, and the other is 'a set of successive waves of business-type managerialism'. Due to "New Public Management", some terms such as managers, service providers, customers, etc., are beginning to gain importance in the public administration discussion.

The main objective of the constituent units of the public sector is to fulfill the public interests through the performance of activity beneficial to society. The concept of the public sector covers not only the totality of public sector institutions, but also their decision-making and implementation in relation to the fulfillment of public interests. The performance of the public sector is mainly related to the implementation of political decisions in an administrative manner, i.e. through the creation of certain rules. ARDA is part of the public service aiming at strengthening and enhancing the economic performance of a vital sector in Albania agriculture sector. As any Agency of the public sector its performance is measured by beneficiary perceptions, which is related to their financial education as well. This is backed by [8] the findings that financial education increases the ability, freedom and confidence of families and companies considering also their economic and social side. Also, in their study, the financial knowledge of beneficiaries creates some premises for assuming that successful applicants are well informed and trained. That's why in the following paragraphs will be given: the methodology used for the measurement of the perception and satisfaction for the service beneficiaries, employees, and managers of ARDA with a focus on the quality and transparency of public services provided; the literature review on performance concept and good governance; and then the main stakeholders' perception on service delivery at the central level by ARDA, focusing on a possible correlation (if any) between the above-mentioned perceptions on performance of public services delivered, in order to increase performance and real welfare.

\section{Methodology}

The measurement of the perception of satisfaction for the service beneficiaries, employees, and managers of ARDA with a focus on the quality and transparency of public services provided, was finalized by combining quantitative and qualitative research techniques [9].

The quantitative component consisted of three questionnaires addressed to beneficiaries: 1) farmers; 2) employees and 3) senior managers of ARDA, using a representative sampling. The questionnaires are anonymous, as their sole purpose is to gather as many valid answers as can be called a credible and valid sample. The reliability and internal consistency of the answers I data collected from the questionnaires was assessed through Cronbach's alpha, which resulted in $>0.700$ for all questionnaires used in the study. The clarity, wording and structure of 
the questionnaires and interviews were tested in a pilot phase with 30 farmers / entrepreneurs, employees and managers and then applied to all respondents included in the study.

The first questionnaire was addressed to farmers, who have benefited from the grants (subsidies) of national schemes for the period 2014-2017 in some regions of Albania (Tirana, Berat, Fieri, Elbasan and Durrës) that were randomly selected. The questionnaires were conducted in face-toface interviews with farmers, grants (subsidies) beneficiaries of national schemes for the period 2014-2017, or by telephone. The data for these farmers (name, surname, residential address, contact number, etc.) were obtained from ARDA, Albanian State Supreme Audit (ASSA) and other public reports $[10 ; 11 ; 11 ; 12 ; 13 ; 14]$. Beneficiary farmers have been contacted in advance by phone to meet and arrange the survey. The field survey was conducted in the regions of Tirana, Berat (olive and agribusiness), Fier, Durres and Elbasan, all farmers randomly selected. The final sample consisted of 245 beneficiary farmers, a representative sample of them based on $95 \%$ confidence interval, $80 \%$ power of this study and $5 \%$ precision, while the number of beneficiary farmers from the five regions in total is 23815 . The sample selected for the survey in each region is proportional to the total number of beneficiaries by region.

In total, the sample includes $8.6 \%(\mathrm{~N}=21)$ females and $91.4 \%(\mathrm{~N}=224)$ males, with significant difference between them $(\mathrm{p}<0.01)$; The active age group is 56-65 years old with $43.7 \%$ of the total participants $(p<0.01)$ and secondary education with $54.7 \%$ of the total participants $(p<0.01)$. The sample of the study was not analyzed by gender, age group and educational level, because they are mainly males and very few females, mainly individual farmers and a small number are cooperatives, where their legal representative was surveyed. Prevalent education is secondary and elementary education.

Meanwhile, the second questionnaire was conducted with ARDA employees from general directorates that provide services to applicants (farmers). Questionnaires were completed online, once directed by e-mail to the Human Resources
Department of ARDA. The study included 97 ARDA employees - a substantial representative sample based on: $95 \%$ confidence interval, $80 \%$ study strength and $0.05 \%$ accuracy (ARDA employees are a total of 130 people). In total, the sample includes $38.2 \%(\mathrm{~N}=37)$ females and $61.8 \%(\mathrm{~N}=60)$ males, with a significant difference between them $(\mathrm{p}<0.01)$, the active young age group predominates $26-35$ years old with $52.9 \%$ of the total participants ( $\mathrm{p}<0.01)$, as well as university degree $(85.3 \%)(\mathrm{p}<0.01)$.

The third questionnaire was addressed to the department heads that provide services to applicants (farmers), such as. Project Selection and Approval Department, Control Department, Payments Authorization Department, Payments Execution Department, etc. The questionnaires were initially completed online, by top executives. ARDA's. Additionally, direct individual semi structured interviews were conducted, as an auxiliary and complementary method, to validate the data from online survey. The study included 6 senior managers in ARDA, representing 6 Departments that provide services to farmers, of which $5(83.36 \%)$ were female and $1(16.7 \%)$ male, with no significant difference between them. $(p=0.2)$. Dominant age group was $36-45$ years with $50 \%$ of the total participants (p $<0.01)$, and all $(100 \%)$ have a university degree.

The qualitative component of the research consisted of two interviews with senior managers and external public auditors. One open-ended interview conducted with 6 Department heads and a semi-structured interview with the auditors of the Performance Audit Department, in the Supreme State Audit. The interviews were all conducted face to face. A total of 11 auditors were interviewed, of which $64 \%$ were male and $36 \%$ female. The predominant age of the interviewed auditors is 25-35 years (63.6\%), while $2(18.2 \%)$ of them are around 56-65 years old. In a smaller percentage, sampling was represented by the age groups $36-45(9.1 \%)$ and 46-55 (9.1\%), respectively, by one participant for both age groups. Of the interviewed auditors, 9 of them $(81.8 \%)$ have a university degree, 1 of them holds a $\mathrm{PhD}(9.1 \%)$, and only $1(9.1 \%)$ claims an unspecified level of education. 
Quantitative data were analyzed by combining descriptive and correlation elements. Meanwhile, qualitative data were analyzed using content analysis. All open-ended questions and qualitative data were coded and categorized, then analyzed. The following are the main findings.

\section{Literature Review}

Despite the great importance of performance and its widespread use, relatively little effort has been made to clarify the concept of performance especially accurately and clearly amongst public sector providers. However, over the last 10-15 years, a growing interest in developing a performance definition can be evidenced. Some authors [15] and [16] agree that the definition of performance should differ between the action aspect (e.g., behavior) and the outcome aspect (e.g., overall performance). Thus, performance is not determined by the action itself, but by the evaluation processes $[17 ; 18 ; 19]$. Moreover, only actions that can be scaled, i.e., measured, constitute performance [15]. Definitions of performance include alternative terms such as fulfillment, achievement, or accomplishment. Most of these terms relate to the effect of public entity actions on the realization of governance objectives, but they also relate to the subjective meaning of satisfaction experienced as a result of one's action. Therefore, accordingly, performance can be defined in terms of effort or in terms of results, without neglecting the subjective dimension of "performance". It is a mistake to completely neglect the subjective dimension of "performance", because it is an important determinant of organizational effectiveness. An entity is assumed to have a good performance if it achieves its objectives successfully, i.e., by effectively implementing an appropriate strategy.

According to research study [20], audit reports serve to ascertain positive findings or violations or deviations from internal procedures, laws, and regulations on banks in Albania. Knowing that ARDA implements the principles of second level banks therefore auditing is crucial for ensuring efficiency and transparence of its activities. While the audit of the performance of a public entity by Albanian Supreme State Audit (ASSA) takes on a special importance for guaranteeing the principles of good governance, such as transparency, accountability, accountability, and active participation. As a public entity, ARDA is obliged to be audited either by its internal audit or ASSA.

The performance of the public sector is mainly related to the implementation of political decisions in an administrative manner, i.e., through the creation of certain rules. Smalskys [21] has identified five characteristic functions for public sector institutions: distribution, regulation, redistribution, institution building, and public service delivery. The concept of the public sector is broad and can be defined in different ways. According to J. E. Lane [22], the public sector means the institutions supported by the central and local budget, which carry out public activity. The public sector provides public products and services, which are not subject to competition and are accessible to any individual. According to Smalskys [21], the public sector should be understood as "the system of organizations that manage and use state resources", while Arimavičiūtė [23] states that "the public sector is a combination of public and private elements". So, the public sector is the totality of institutions, which are financed by the state budget. To generalize the whole concept, we can say that the public sector is state finances (funds, shares, etc.), tangible resources (land, buildings, etc.) and human resources (managers and employees paid from central and local budget funds), the processes that change these resources as well as the products of these processes (public and administrative services, individual and normative legal acts, expenditures and investments)" [21]. Regarding the public sector, it is extremely important to distinguish between the constituent entities attributed to this sector. First, public administration is a set of entities that jointly exercise activities that aim to respond to the needs of a general interest of the population (education, public order, health, social services, food security, etc.).

Therefore, this study will provide an aspect of governance in Albania, focusing on the level of satisfaction of stakeholders in relation to the activity of the Agency for Agricultural and Rural 
Development (ARDA) by considering a representative sample.

The evaluation of the institutional performance on the quality of the public services provided by governmental agencies, is based on the level of satisfaction collected by the public opinion, where the best measure is the citizens' satisfaction. Citizens' satisfaction is in fact a pool of perceptions on the value of the service received, where the value is equal to the quality of the service perceived above the price [24]. According to Fornell [24] the main determinant of overall satisfaction is the perceived quality.

These approaches on the quality of public services and the level of civic satisfaction, raise the issue of the importance of measuring and evaluating them at the level of government. Considering the limited amount of studies /research in this area, this particular study was undertaken to assess the three-dimensional perception of governance and its performance: (i) the perception of employees of the public service provider institution (ARDA); (ii) the perception of those who lead this institution; (iii) and the perception of the beneficiaries who receive services from this institution. More specifically, the survey data collected from farmers beneficiaries of national support schemes (including agro-processors) are analyzed to understand their level of satisfaction from the services provided by ARDA and the performance of the institution as a whole. This category of farmers has been also selected due to their commitment to become promoters of agricultural development through various initiatives that are financially supported by national schemes. But still, one research study [25] on lending in developing countries concluded that there is lack of lending which create barriers for their development and specially for farmers. National support schemes are of a great public interest and the efficient administration and use of budget funds by ARDA, avoiding or minimizing the misuse and theft of public funds, is a priority for all stakeholders.

The need to assess the quality of public service is closely related to the establishment of indicators, as part of the overall assessment of the public sector, where the main goal is the further consolidation of the governing institution (ARDA in this case), as well as improving services provided aiming at the increase of satisfaction of rural actors that benefited from these services. The correlation between perceptions, to improve institutional performance and foster social well-being of the beneficiaries will be part of analyses of this study. Literature studies [26; 27] suggest that understanding and analyzing the views from three different perspectives, starting with the governance of the audited lenders (ARDA), its employees and finally the beneficiaries (stakeholders) of these public funds, whether real or perceived, is of an imperative importance for improving the quality of public services, transparency, and accountability of the public entity such as ARDA and, consequently, its activity for the benefit of its stakeholders either as taxpayers or borrowers.

\section{Analysis}

\subsection{Perception of beneficiary farmers on the services provision at the local offices of ARDA}

Regarding the provision of services by ARDA, a minority of farmers of $29.8 \%$ agree that: 1) administration and distribution of budget funds for the development of agriculture and rural areas by ARDA meets the requirements of the agricultural sector; and 2) agricultural and rural development policy measures implemented by ARDA are appropriate. Meanwhile, more than half of the surveyed farmers $(69.8 \%)$ are neutral regarding these issues. An even smaller proportion of survey participants (20\%) agree that the administration and distribution of these budget funds has been fair, transparent, and efficient, while most of them $(80 \%)$ are against. Although $90.2 \%$ of respondents say they agree that the number of support schemes has increased from year to year, all surveyed farmers unanimously claim that the number of applications and benefits from support schemes has decreased; this is due to various shortcomings in the information and public advisory system related to general and specific criteria (procedures, documentation, types of eligible 
investments, etc.). In fact, $69.8 \%$ of farmers report that they are not informed about the IPARD 2014-2020 program, and only a minority of them $(29.8 \%)$ who are large entrepreneurs, have information.

Farmers participating in the study were asked how satisfied they were with resolving/ reviewing of their complaints and to what extent they trusted the institution of ARDA. The results of the survey highlighted the need to improve various requests and complaints procedures. A minority of $9.8 \%$ of respondents expressed that they are dissatisfied with the way their complaints were approached by ARDA staff. They think that complaints management is not performed according to the standards, and that the observance of the deadlines set by the institution is mediocre. On the other hand, only $20 \%$ of respondents are satisfied with the resolving/ reviewing of complaints, while most of them (69.8\%) stated that they are "somewhat satisfied".

Public credibility remains a key element for the successful functioning of the governmental agencies. Based on the data analysis, a minority of farmers surveyed (20\%) believe that institutions providing public services to the farmers' requests, respond comprehensively, fairly and in due time as well as per service delivery standards. However, most of them say that they "somewhat trust" $(69.8 \%)$ and "do not trust" $(9.8 \%)$ in state institutions in general and ARDA in particular. The institution trust and satisfaction level of farmers beneficiaries towards services provided tend to go hand in hand with low exceptions.

In the case of public services provided by governmental agencies (ARDA), there are fewer respondents who do not trust the system $(9.8 \%)$ than respondents dissatisfied with the provision of services and the performance of the institution $(69.8 \%)$. These findings demonstrate the moderate confidence of entrepreneurs (farmers) in the system (69.8\%), which does not compromise their willingness to respond to public policies, thus promoting sustainable economic and environmental development. Although largely dissatisfied with the performance of the institution and the quality of service provided during the period 2014-2017, respondents $(69.8 \%)$ say that their perception of this institution's performance has not changed even after 2017 (i.e., after the audit of performance by SSA- Supreme, State, Audit); The exception is the surveyed farmers who benefit from the support schemes every year, as they are satisfied with the institutional performance $(29.8 \%)$. It is worth noting that one of the highly rated components was the ARDA staff itself and, more specifically, the following indicators: 1) staff communication and overall positive behavior (100\%); 2) staff readiness and positive attitude towards farmers $(69.8 \%)$.

The study also analyzed some indicators for technology use to examine the electronic interaction between ARDA and farmers in five regions of Albania. E-government has brought about fundamental changes in the communication and service environment for farmers. The data show that a high percentage of surveyed farmers (80\%) do not use the ARDA electronic service for various reasons, among which it is worth mentioning the following: 1) they are not aware of ARDA website; 2) do not have internet access (from home or mobile); 3) have difficulties in using this service. So, their access to this type of service is quite low; only $20 \%$ of farmers $(\mathrm{N}=$ 49) use ARDA electronic service. Only farmers that have used the electronic service from Tirana region, were asked to answer other questions in the section "Electronic service provided by the ARDA". From all citizens who use the electronic service within Tirana Region, most of them declare they agree and fully agree that this service offers easiness of use and plenty of information.

\subsection{Staff perception on service delivery at the central level by ARDA}

Almost all surveyed ARDA employees report that the beneficiary farmers are satisfied with the quality of services provided, because the administration and distribution of loans by ARDA has met the current needs of the 
agricultural sector (85.3\%), and has been fair, transparent, and efficient $(82.3 \%)$. According to them, the quality of services to the beneficiary farmers and consequently the satisfaction of the latter with the Agency is outstanding. Moreover, $67.6 \%$ of respondents say that users of services provided by ARDA trust the institution; a minority of them say that beneficiaries have a high level of trust (8.8\%) and some trust $(20.6 \%)$ in ARDA, and only $2.9 \%$ of them think that farmers have no trust in the institution at all. Employees surveyed also report that farmers are very satisfied and satisfied with the complaint's management $(76.4 \%)$, while a minority of them report that they are somewhat satisfied $(20.6 \%)$ and dissatisfied $(2.9 \%)$. Moreover, they claim that the institution has implemented the appropriate measures of agricultural and rural development policies $(85.3 \%)$, while increasing the number of support schemes from year to year $(79.5 \%)$. Moreover, more than $60 \%$ of them oppose the public claim that the number of farmers applying and/or benefiting from government support schemes and donor grants has decreased due to shortcomings in the public information channels and a confusing advisory system related to the general and specific criteria (such as procedures, documentation, eligible investments, etc.). More than half of the respondents $(58.7 \%)$ indicate that the performance of the institution has continuously improved during the period 2014-2017 and that farmers are satisfied with the performance of ARDA at $58.8 \%$. Institutional performance has improved after the performance audit and consequently the data show that the level of satisfaction of farmers, according to staff, reaches the value of $67.7 \%$; while $8.8 \%$ of respondents state that farmers are very satisfied with the current performance of ARDA.

As employees are considered the main contributors of performance, their work quality analysis was considered of an increased importance. Therefore, employees were asked how they would evaluate the work of ARDA staff from the beneficiary farmers point of view. The survey showed that most employees agree and fully agree that ARDA staff: 1) is always on the alert of farmers $(94.1 \%)$; 2) treats the farmers with respect and courtesy $(97 \%) ; 3$ ) responds to the requests of farmers within a reasonable time $(97.1 \%)$.

\subsection{Perception of senior management on service delivery at the central level by ARDA}

Regarding the provision of services at the central level, almost all surveyed managers say that the beneficiary farmers are satisfied with the quality of services provided, because the administration and distribution of loans by ARDA has met the current needs of the agricultural sector $(83.3 \%)$, and has been fair, transparent, efficient (100\%). According to them, the service quality to the beneficiary farmers and consequently the satisfaction of the latter with the governmental agency is high. Moreover, $83.3 \%$ of the respondents $(\mathrm{N}=4)$ say that the users of the services provided by ARDA trust the institution; one manager states that they have a lot of trust $(16.7 \%)$ and the other that they have some confidence $(16.7 \%)$ in ARDA. Half of the managers participating in the study also report that farmers are very satisfied $(16.7 \%)$ and satisfied $(33.3 \%)$ with the handling of complaints to the extent $(76.4 \%)$, while the other half report that farmers are somewhat satisfied (50\%). Moreover, they claim that the institution has implemented the appropriate measures of agricultural and rural development policies $(83.3 \%)$, while increasing the number of support schemes from year to year $(100 \%)$.

Therefore, out of six respondents, three oppose the public claim that the number of farmers applying and / or benefiting from government support schemes and grants has decreased due to shortcomings in the public information and counseling system, related to general and specific criteria (such as procedures, documentation, eligible investments, etc.); while two of the respondents are neutral and one agrees. In this context, more than half of the respondents show that the performance of the institution has continuously improved during the period 20142017 and those farmers are satisfied and very satisfied with the performance of ARDA at $66.7 \%$. Institutional performance has 
significantly improved after the performance audit and consequently the data show that $83.3 \%$ of surveyed managers say that farmers are satisfied and somewhat satisfied (16.7\%) with the current performance of ARDA.

\subsection{Is there a significant correlation between the perception of ARDA employees and the perception of farmers, to improve institutional performance?}

Figure 1: Correlations of farmers' statements with ARDA staff statements

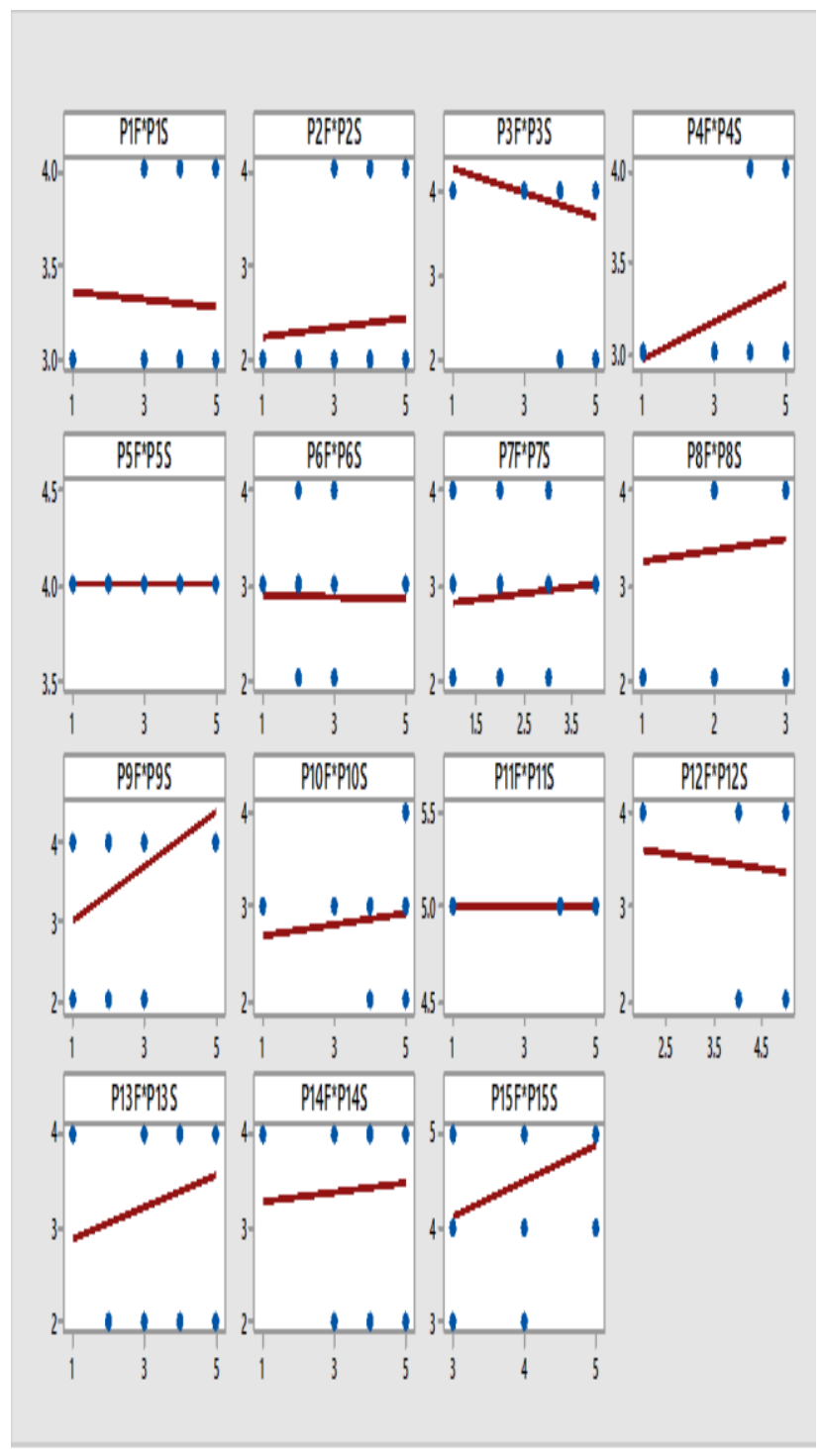

Figure 2: Correlations of farmers' claims with the claims of ARDA executives

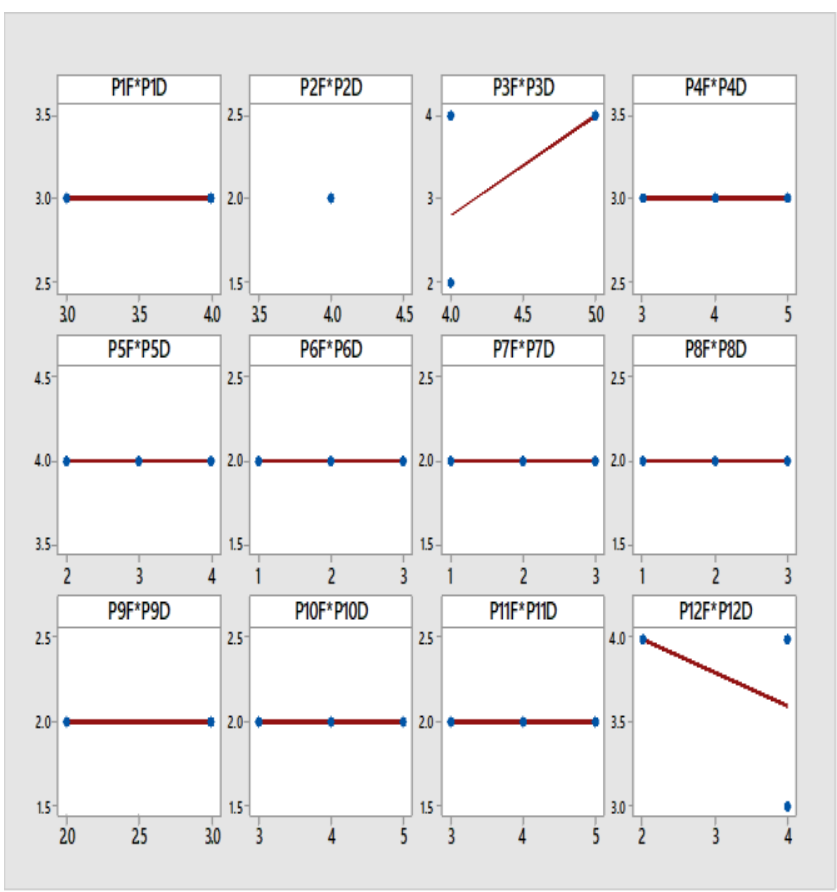

The results of the data analysis show that there is no significant correlation between the assertions of the farmers and the assertions of the ARDA staff regarding the questions in Table 1, Annex 1.

Over $50 \%$ of farmers are dissatisfied with the performance of the institution during the period January 2014 - September 2017; the exception is farmers who benefit each year from support schemes.

The study shows that the ARDA staff tends to overestimate the performance of the institution, compared to farmers benefiting from national schemes. More specifically, they say that despite the increase in the number of support schemes from year to year, the number of applicant farmers and consequently those beneficiaries have decreased. This is due to shortcomings in the public information and advisory system for farmers, related to general and specific criteria, referring not only to farmers applying for government support schemes, but also to those applying for grants (loans). More than half of farmers (mostly small entrepreneurs) are not informed about the IPARD 2014-2020 program. Farmers even say that the handling of complaints is not done independently, impartially, in a timely manner and in their interest. 
Figure 3: Comparison of the mean score between survey responses by farmers and employees \& ARDA Executives.

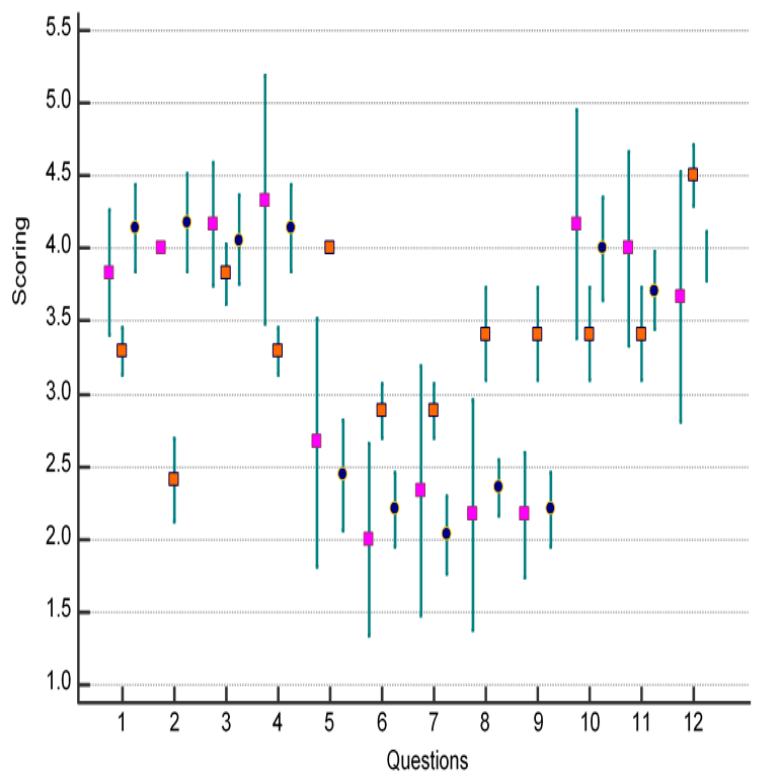

The results of the data analysis show that the mean scoring of farmers' assertions differs compared to the scoring of ARDA staff assertions. The study shows that ARDA staff tends to overestimate the performance of the institution, compared to farmers. It means that ARDA staff is prone to give higher evaluation than farmers on the institutional performance they work in. However, most of them still think that the central government performance needs further improvement.

We can, therefore, conclude that there is no statistically significant correlation between the perception of ARDA employees and the perception of farmers, to improve institutional performance. Statistically significant correlation exists only between the perception of ARDA staff and Executives. This clearly proves the existence of a large divide between officials and the community.

\section{Conclusions}

The study concludes that the performance of the ARDA has an impact on the quality of public services provided to farmers and the real wellbeing in our country. According to the farmers' perception, all the performance indicators of the ARDA institution that have been analyzed in this study are not at the expected level. According to them, the administration and distribution of budget funds by the institution has not met the requirements of the agricultural sector. In relation to this issue, they are particularly dissatisfied with indicators such as: impartiality, proportionality, transparency, and efficiency.

All farmers request from ARDA: 1) facilitation of application procedures, reducing financial and time costs for them; and 2) solving the problem of disbursement of funds, improving their efficiency.

The results of the analysis of data and indicators show that the opinion of farmers benefiting from budget funds shows low levels of satisfaction with the quality of public services. Therefore, it is concluded that public institutions in Albania need further performance improvement. In general, the governance capacity in this sector to provide quality services is relatively limited, due to difficulties in infrastructure, service delivery systems, human resource capacity and the necessary financial resources.

\section{Recommendations}

Within the identified management issues in this sector, some essential recommendations are drafted as follows:

1. Transparent communication with farmers and symmetric criteria for benefiting by financing or credit guarantee schemes donated by public and EU funds for Albanian farmers.

2. Simplification of application procedures for farmers (such as simplification of national schemes, online verification of data and reduction of the list of required documentations, therefore minimizing time and costs for them).

3. Based on European best practices and successful stories by Albanian scientific researchers to be designed the appropriate credit 
scheme for farmers using the public and EU funds ${ }^{1}$.

\section{References:}

[1] Christopher Hood, (1991) "The rise of 'new public management".

[2] Ferlie E. \& Steane P. (2002). "Changing Development in NPM". International Journal of Public Administration", 25(12), 1459-69.

[3] Hans, D. B., Managing Performance in the Public Sector, 2nd Edition, Routledge, Taylor and Francis Group, pp. $17-33,2007$.

[4] Hood, C. (1995). "Contemporary public management: a new global paradigm?". Public Policy and Administration, pp. 95- 98.

[5] Osborne, S. P. (2006). "Editorial: The New Public Governance?". Public Management Review, 8(3): 377-87. Taken from: https://paulallen.ca/documents/2015/07/ osborne-sp-the-new-public-governance2006.pdf/.

[6] Pollitt C., Bouckaert G. (2011). "Public Management Reform - A Comparative Analysis: New public management, Governance, and the Neo-Weberian State". (3rd edition), Oxford University Press, Oxford.

[7] St. Dwiarso Utomo, Zaky Machmuddah, Melati Oktafiyani, The Associations Between Earnings Management, Corporate Environmental Disclosure, Corporate Financial Performance and Corporate Governance Mechanisms, WSEAS Transactions on Business and Economics, ISSN / E-ISSN: 1109-9526 /
2224-2899, Volume 16, 2019, Art. \#39, pp. 345-354.

[8] Ribaj A., Meçe M., Cinaj V., Kadrimi I., (2020). Issues related to financial education of youth in a developing country (the case of Albanian youth). WSEAS Transactions on Business and Economics, 17, 140-152. https://doi.org/10.37394/23207.2020.17. 16.

[9] Cresswell, J. W., Research design: Qualitative and quantitative approaches. Thousand Oaks: Sage, 2007.

[10] Supreme State Audit (2018). "Development Strategy of KLSH 20182022". Taken from: http://www.klsh.org.al/web/Strategjia_e _Zhvillimit_te_KLSH_se_2018_2022_P lani_Strategjik_EUROSAI_2017_2023_ Plani_Strategjik_INTOSAI_2017_2022 _3450_1.php.

[11] Supreme State Audit (2019). "Annual Performance Report 2018". Taken from: http://www.klsh.org.al/web/raporti_perf ormances_2018_4788.pdf.

[12] Supreme State Audit, Performance Audit Department (2018). "Performance audit in KLSH", Experience 2018, 2, Tirana. Taken from: http://klsh.org.al/web/kopertina auditim i_i_performances_4625.pdf

[13] Law no. 154/2014, "On the organization and functioning of the Supreme State Audit"

[14] International Monetary Fund (2014). "Government Finance Statistics Manual 2014". Joint Bank-Fund Library, 24-26. ${ }^{1}$ (This will be a direction of our future research in
this area). 
[15] Campbell, J. P., McCloy, R. A., Oppler, S. H., \& Sager, C. E. (1993). "A theory of performance".

[16] Kanfer, R. (1990). "Motivation theory and industrial and organizational psychology". In Dunnette M. D. \& Hough L. M. (Eds.). "Handbook of industrial and organizational psychology" (2nd edition), Vol. 1, 75170. Palo Alto, CA: Consulting Psychologists Press.

[17] Ilgen, D. R., \& Schneider, J. (1991). "Performance measurement: A multi-discipline view". Në Cooper C. L. \& Robertson I. T. (Eds.), International review of industrial and organizational psychology, 6, 71-108. Chichester: Wiley.

[18] Motowidlo, S. J., Borman, W. C., \& Schmit, M. J. (1997). "A theory of individual differences in task and contextual performance". Human Performance, 10, 71-83.

[19] Schmitt E., Borman W. C., \& Associates (Eds.), "Personnel selection in organizations", 35-70. San Francisco: Jossey-Bass.

[20] Cinaj V., Meçe M., Ribaj A., Kadrimi I., (2020). The need for improvement of external audit reports of banks (the case of banks in Albania which mainly belong to EU Banks). WSEAS Transactions on Business and Economics, 17, 539-547. https://doi. org/10.37394/232015.2020.16.55.
[21] Smalskys V. (2010). Viešasis valdymas: vadovèlis. Vilnius: Mykolo Riomerio universitetas. pp. 90-120.

[22] Lane, J. \& E.Vilnius (2005). "Viesasis sektorius Margi raštai".

[23] Arimavičiūtė M. (2005). Viešojo sektoriaus instituciju strateginis valdymas: vadovėlis. Vilnius. pp. 72-79.

[24] Fornell, C., Johnson, M.D., Anderson, E.W., Cha, J., Bryant, B.E., The American customer satisfaction index: Nature, purpose, and findings, Journal of Marketing, 1996.

[25] Ribaj, A., Mexhuani, F. The impact of savings on economic growth in a developing country (the case of Kosovo). J Innov Entrep 10, 1 (2021). https://doi.org/10.1186/s13731-020$\underline{00140-6}$

[26] Ribaj A. and Ilollari O., (2019). Asymmetric information versus banks' costumer trust, Albania case linked with SEE countries. WSEAS Transactions on Business and Economics, 16, 288-297.

[27] Ribaj A., Ilollari, O., Scalera, F., (2019). The unethical banking costs distrust of bank customers (Albania case as a model for SEE countries). WSEAS Transactions on Business and Economics, 16, 582-592.

\section{Creative Commons Attribution License 4.0 (Attribution 4.0 International, CC BY 4.0)}

This article is published under the terms of the Creative Commons Attribution License 4.0 https://creativecommons.org/licenses/by/4.0/deed.en_US 


\section{Annex}

Overview of questionnaire for beneficiary farmers, ARDA employees and executives

\begin{tabular}{|c|c|c|}
\hline Questions & Farmers & ARDA employees \\
\hline $\mathrm{P} 1$ & $\begin{array}{l}\text { 4. Administration and budget allocation by } \\
\text { ARDA of agriculture and rural development in } \\
\text { regions have met the funding demands from the } \\
\text { agricultural sector. }\end{array}$ & $\begin{array}{l}\text { 4. Administration and budget allocation by ARDA } \\
\text { of agriculture and rural development in regions } \\
\text { have met the funding demands from the agricultural } \\
\text { sector }\end{array}$ \\
\hline $\mathrm{P} 2$ & $\begin{array}{l}\text { 5. Administration and budget allocation by } \\
\text { ARDA has been impartial, transparent, and } \\
\text { efficient. }\end{array}$ & $\begin{array}{l}\text { 5. Administration and budget allocation by ARDA } \\
\text { has been impartial, transparent, and efficient. }\end{array}$ \\
\hline P3 & 6. Financing grants number has risen every year. & $\begin{array}{l}\text { 6. The budget amount and number of financing } \\
\text { grants increased every year. }\end{array}$ \\
\hline P4 & $\begin{array}{l}\text { 7. ARDA, as an institution, has implemented } \\
\text { appropriate measures of agricultural and rural } \\
\text { development policies. }\end{array}$ & $\begin{array}{l}\text { 7. ARDA, as an institution, has implemented } \\
\text { appropriate measures of agricultural and rural } \\
\text { development policies. }\end{array}$ \\
\hline P5 & $\begin{array}{l}\text { 8. Shortcomings in the public information and } \\
\text { advisory system for farmers regarding general } \\
\text { and specific criteria (procedures, documentation, } \\
\text { eligible investments, etc.) have reduced the } \\
\text { number of farmers applying and farmers } \\
\text { benefiting from government support schemes and } \\
\text { donors' grants }\end{array}$ & $\begin{array}{l}\text { 8. Shortcomings in the public information and } \\
\text { advisory system for farmers regarding general and } \\
\text { specific criteria (procedures, documentation, } \\
\text { eligible investments, etc.) have reduced the number } \\
\text { of farmers applying and farmers benefiting from } \\
\text { government support schemes and donors' grants }\end{array}$ \\
\hline P6 & 10. To what extent do you trust the institution? & $\begin{array}{l}\text { 10. To what extent do farmers trust ARDA as an } \\
\text { institution? }\end{array}$ \\
\hline P7 & $\begin{array}{l}\text { 11. How satisfied are you with the handling of } \\
\text { complaints? }\end{array}$ & $\begin{array}{l}\text { 11. How satisfied are farmers with the handling of } \\
\text { complaints? }\end{array}$ \\
\hline P8 & $\begin{array}{l}\text { 12. To what extent were you satisfied with the } \\
\text { performance of the institution during the period } \\
\text { January } 2014 \text { - September } 2017 \text { ? }\end{array}$ & $\begin{array}{l}\text { 12. To what extent were farmers satisfied with the } \\
\text { performance of the institution before the auditing } \\
\text { from SSA? }\end{array}$ \\
\hline P9 & $\begin{array}{l}\text { 13. To what extent are you satisfied with the } \\
\text { current performance of the institution? }\end{array}$ & $\begin{array}{l}\text { 13. To what extent are farmers satisfied with the } \\
\text { current performance of the institution? }\end{array}$ \\
\hline $\mathrm{P} 10$ & 14. ARDA staff is always on standby of farmers. & 14. ARDA staff is always on standby of farmers. \\
\hline P11 & $\begin{array}{l}\text { 15. ARDA staff treats the farmer with respect and } \\
\text { courtesy. }\end{array}$ & $\begin{array}{l}\text { 15. ARDA staff treats the farmer with respect and } \\
\text { courtesy. }\end{array}$ \\
\hline P12 & $\begin{array}{l}\text { 16. ARDA staff responded to your requests in a } \\
\text { timely manner. }\end{array}$ & $\begin{array}{l}\text { 16. ARDA staff responded to farmers' requests in a } \\
\text { timely manner. }\end{array}$ \\
\hline P13 & $\begin{array}{l}\text { 27. Facilitation of application procedures for } \\
\text { farmers is needed, thus reducing financial and } \\
\text { time costs for them. }\end{array}$ & $\begin{array}{l}\text { 23. Facilitation of application procedures for } \\
\text { farmers is needed, thus reducing financial and time } \\
\text { costs for them. }\end{array}$ \\
\hline P14 & $\begin{array}{l}\text { 31. ARDA performance needs to be improved in } \\
\text { relation to stakeholder participation in important } \\
\text { discussions and decision-making. }\end{array}$ & $\begin{array}{l}\text { 25. ARDA performance needs to be improved in } \\
\text { relation to stakeholder participation in important } \\
\text { discussions and decision-making. }\end{array}$ \\
\hline P15 & $\begin{array}{l}\text { 24. ARDA needs to improve the efficiency and } \\
\text { effectiveness of the use of budget funds for } \\
\text { farmers. }\end{array}$ & 27. The institution needs improvement. \\
\hline
\end{tabular}

